原 著

2007年 論文受付

論文受理

2008年 1 月30日

Code No. 522

\section{エッジ法によるpresampled MTFの 簡便な解析方法の提案と検証}

\author{
東出 了・市川勝弘 ${ }^{1)} \cdot$ 國友博史・澤田道人 ${ }^{2)}$ \\ 名古屋市立大学病院中央放射線部 \\ 1 ) 金沢大学大学院医学系研究科保健学専攻 \\ 2)安城更生病院放射線技術科
}

\section{緒 言}

Computed radiography $(\mathrm{CR})$ やflat panel detector (FPD)などディジタル一般撮影装置における presampled modulation transfer function (presampled MTF)の測定 法として，近年，金属プレートを用いた方法(エッジ 法)が注目されている。従来から多く用いられている スリット法は $0.01 \mathrm{~mm}$ 程度の幅に垂直に入射するX線 だけを通過させるため，スリットおよびX線管球を正 確に配置する必要があり，アライメント制御と維持の ための補助具を必要とするなど画像取得に工夫が必要 となる。その点においてエッジ法はX線の斜入射によ る影響について考慮する必要はあるものの，画像の取
得は容易である。

International Electrotechnical Commission (IEC) ${ }^{1)}$ に よって採用されたエッジ法は，エッジを約 $1.5 〜 3.0^{\circ}$ 傾 けて撮影し，エッジを横切る方向の複数ラインのプロ ファイルを合成することによりサンプリング間隔の細 かい合成プロファイルを得る。これに対して必要に応 じて線形化を行い，微分することでline spread function (LSF) を計算して，フーリエ解析によりMTFの算出を 行う。Buhrら ${ }^{2)}$ は，傾けたエッジの角度によって合成 に使うライン数を決定している。そして，合成の際に 解析が容易に行えるように，合成後の各点の配置を理 論的な配置とは異なる均等な間隔で調整して合成プロ

\title{
Proposal and Verification of Presampled MTF Measurement by the Simple Analysis Method Using the Edge Method
}

\author{
Ryo Higashide, Katsuhiro Ichikawa, ${ }^{1)}$ Hiroshi Kunitomo, and Michito Sawada2) \\ Central Department of Radiology, Nagoya City University Hospital \\ 1)Division of Health Sciences, Graduate School of Medical Science, Kanazawa University \\ 2)Department of Radiological Technology, Anjo Kosei Hospital
}

Received Sept. 19, 2007; Revision accepted Jan. 30, 2008; Code No. 522

\section{Summary}

The edge method adopted by the International Electrotechnical Commission(IEC) for presampled modulation transfer function (presampled MTF) measurement has the advantage that the complexity and limitations of image acquisition are less than those of the slit method. On the other hand, it has the disadvantage that the maintenance of accuracy is difficult because of the noise amplification caused by the differentiation. In order to reduce this disadvantage, we proposed an effective method in which many edge profiles are synthesized and then the synthesized edge profiles are bound into regular interval bins. Furthermore, the influences of some factors in edge profile analysis on measurement accuracy were examined. The appropriate width of one bin was $10-20 \%$ of the sampling interval. Measurement error of the inclination angle of the edge should be made up to $0.05^{\circ}$. The range of the angle was allowed to be from 1 to 5 degrees. If these conditions were fulfilled, accurate measurement up to the Nyquist frequency(fn) was possible. Using an actual computed radiography $(\mathrm{CR})$ system, the presampled MTF was obtained by the slit method and our edge method. The two results showed good agreement.

Key words: modulation transfer function (MTF), digital imaging system, presampled MTF, edge 
ファイルを得る方法について報告している。この方法 では理論的配置と調整後の配置の差が大きいほどMTF の結果における誤差が大きくなる。さらに，解析過程 の微分操作によってノイズが増幅されるために安定し たMTFの測定を行うことが難しいという問題点もあ る。また, Sameiら ${ }^{3)}$ はノイズの軽減を目的にedge spread function $(\mathrm{ESF})$ の平滑化や曲線近似を行ってお り，スリットとエッジで実測したMTFの比較では, エッジ法においてノイズを軽減させるための平滑化の 影響でナイキスト周波数以下のMTF值が低下してい る。これらの報告から，エッジ法における誤差要因が 多いことは明らかであり，これを軽減し，より正確に MTFを求めるための解析方法が必要である.われわれ の提案する手法は，傾斜したエッジ像から広範囲の デー夕点を合成してプロファイルを得て，これらを後 述する一定間隔のbinを用いて平均化することで，等 間隔となる合成のESFを取得する方法である。

本論文では，提案する手法についてコンピュータシ ミュレーションによる精度の確認およびさまざまな因 子のpresampled MTF測定值への影響について述べ る。また，CR装置を用いた実測によるスリット法と の比較についても述べる。

\section{1. 方 法}

\section{1-1 提案手法におけるpresampled MTFの解析方法} われわれの提案するエッジ法によるpresampled MTF の解析方法は, Buhrらやその他の報告 ${ }^{2,4 \sim 6)}$ の方法と 同様に約 $2 \circ$ 傾けたエッジ像を利用する。これにより エッジ像から合成プロファイルを作成することができ るが，われわれの手法では，この際に，Buhrらのよう に合成のためのライン数を傾斜角度から決定せず，角 度に応じて広い範囲の二次元的データを一次元上に投 影して合成プロファイルを得る。Fig. 1は5×5マトリク スのエッジデータでの本手法におけるプロファイルの 合成方法を示したものである。眓のように，合成後の 位置はA行の $1 ， 2 ， 3 ， 4 ， 5$ それぞれのデー夕間隔は 検出器のサンプリングピッチPであり，1 列のA，B， $\mathrm{C}, \mathrm{D}, \mathrm{E}$ れぞれの合成後のデータ間隔はエッジの傾 斜角度： $\theta$ に依存して $\mathrm{P} \times \tan \theta$ となる。しかし，各列の デー夕を重ねるように合成すると合成後のデータの間 隔が不均等となり，このままでは，フーリエ変換する ことは困難である。そこで，不均等な間隔のデー夕を Fig. 2 (a)のように一定の幅を持つbinを設定して，それ ぞれのbin内に収まるデー夕点を平均化することで, Fig. 2(b)のような均等間隔のデータに変換する手法を 取った。このbinによる平均化処理には，間隔を均等 にするだけでなく，平滑化の効果もあり，後の微分処 理によるノイズ強調を抑制する。得られた合成プロ

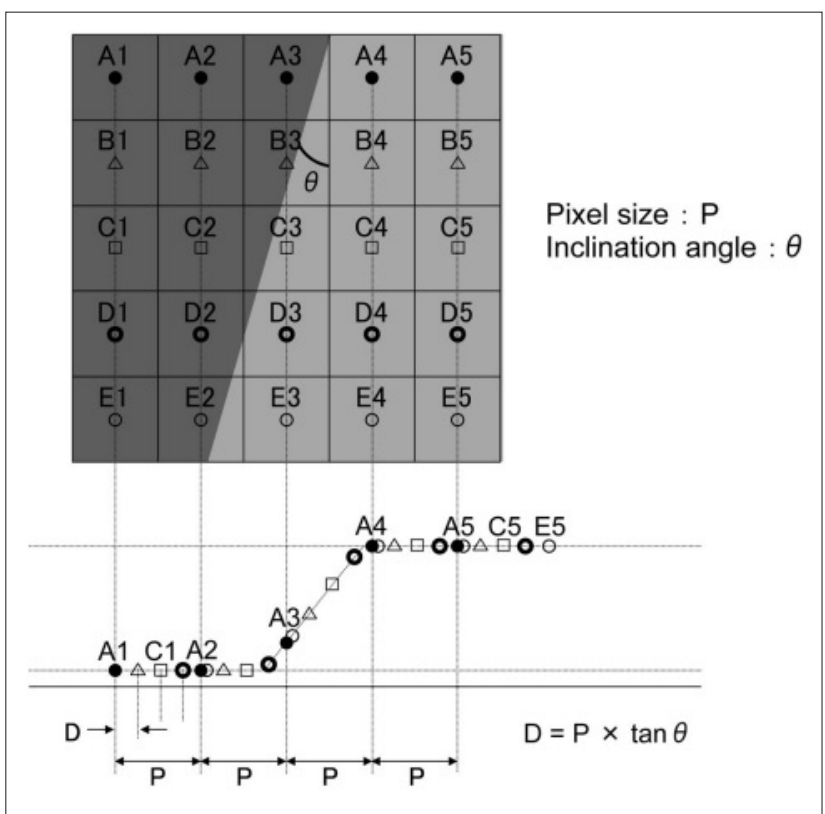

Fig. 1 Schema of edge profile synthesis in the proposed method (example of $5 \times 5$ matrix).

ファイルは必要に応じてディジタル特性曲線7を用い て線形化を行い，合成のESFとする。そして，ESFを 微分することでLSFを得て, truncation error ${ }^{8)}$ を防ぐた めにLSFに外挿処理9,10)を行い，フーリエ変換111によ り presampled MTFを算出する。このとき， binによる 平滑化と隣接差分の影響を考慮して sinc関数による補 正 ${ }^{12)}$ を行う。この際に用いる補正係数は次式で表され る.

$$
\frac{1}{\operatorname{sinc}(\pi \cdot f /(2 \cdot f c))}=\frac{\pi \cdot f /(2 \cdot f c)}{\sin (\pi \cdot f /(2 \cdot f c))}
$$

$\mathrm{f}$ : 空間周波数 [cycles $/ \mathrm{mm}$ ]

$\mathrm{fc}$ ：合成後の均等間隔となったプロファイルのナイキ ス卜周波数 [cycles $/ \mathrm{mm}$ ]

Fig. 3に本手法の解析手順を示す.

\section{1-2 コンピュータシミュレーションによる本手法の} 精度の検討

\section{1-2-1 基本的な精度の検討}

シミュレーションによりガウス関数による既知の MTF (真值)を持つエッジ像のデータを作成して, 測定 值と真值の比較を行い，本手法が妥当な結果を導き出 すことができるかを検証した。シミュレーションにて 作成するエッジ像は，元の画像データとして0.001 mm の非常に細かい間隔の画像データより作成して, 正確 なシミュレーションとなるようにした．解析に用いる シミュレーションによるエッジ画像のサンプリング ピッチは $0.1 \mathrm{~mm}$ とした。エッジの傾斜角度は過去の報 告から妥当と思われる $2^{\circ}$ と， binの幅は，その影響 


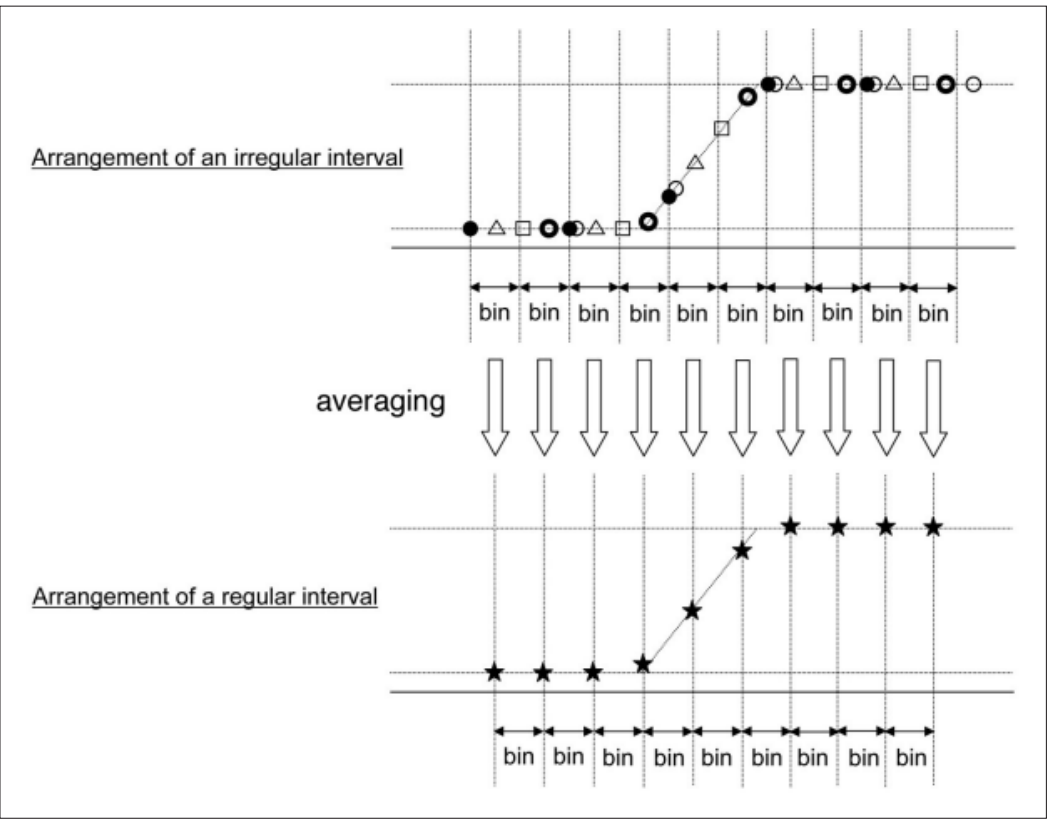

\section{a \\ b}

Fig. 2 Outline of the method with which the synthesized profile with irregular interval was converted into a profile data with regular interval using the regular interval bins.
が少ないと考えられる0.01 $\mathrm{mm}$ 用いた。

\section{1-2-2 各因子の測定值への影響の検討}

本手法を用いた場合の影響因子として，エッジの傾 斜角度，binの幅，エッジ角度の計測誤差，およびノ イズが考えられる。これらの影響を検討するためにシ ミュレーションによるエッジ像を用いて，各因子を変 化させてpresampled MTFを算出し真值と比較した。 なお，以下のa)，c），d）に用いるbinの幅は0.01 $\mathrm{mm}$ と して，合成プロファイルを作成するために用いる範囲 は180×180ピクセルとした。

\section{a)エッジの傾斜角度の影響}

1 $5^{\circ}$ 内の角度において $0.2^{\circ}$ 間隔で変化させてナイキ スト周波数 $(\mathrm{fn})$ とその半分の周波数 $(\mathrm{fn} / 2)$ での真值と の誤差率の変動を求めた。

\section{b) binの幅による影響}

解析手順として $180 \times 180$ ピクセルのデー夕点に対し て $\tan \theta$ を使って合成を行い，不均等間隔の合成プロ ファイルをbinによって均等な間隔に変換する。この 際に用いる binの幅を $0.01 ， 0.02$ および $0.03 \mathrm{~mm}$ と変化 させ，エッジの傾斜角度が $1 \sim 5^{\circ}$ 内の角度において $0.2^{\circ}$ 間隔で変化させて周波数 $\mathrm{fn}$ と $\mathrm{fn} / 2$ での真值との誤 差率の変動を求めた。

c) エッジの角度の計測誤差による影響

傾斜角度が $1 ， 2 ， 3 ， 4 ， 5^{\circ}$ のエッジ画像に対してこ の真の角度から $0.01^{\circ}$ 間隔で合成に用いる角度を変化 させて周波数 $\mathrm{fn}$ と $\mathrm{fn} / 2$ での真值との誤差の変動を求め た。

\section{d）ノイズによる影響}

実際にMTF測定を行う画像はノイズを含むため，傾 斜角度が $2^{\circ}$ のエッジ画像に正規分布ノイズを付加し

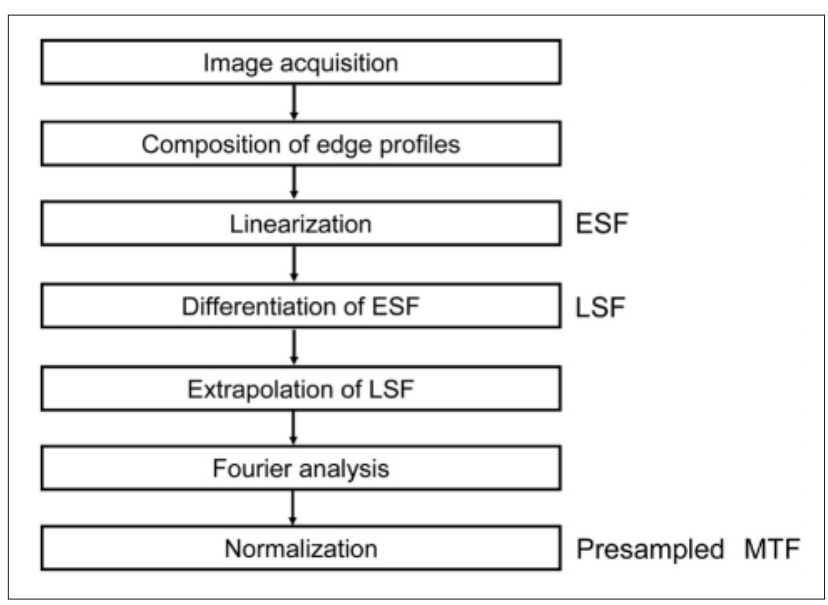

Fig. 3 Procedure of analysis of presampled MTF measurement by the proposed method.

て，その画像から本手法およびBuhrらの方法にて presampled MTFを算出し，両者の結果を真值と比較 した.

1-3 CR装置を用いた実測によるスリット法との比較 前項で検討した結果をもとに，CR装置を用いて presampled MTFの実測を行った。CR装置はコニカミ ノルタ社製Regius model 170を用い，サンプリング ピッチが0.175mmのモードの画像を採用した。エッジ はIECの規格に準拠した厚さ $1 \mathrm{~mm}$ タングステン製のも ので，スリットはスリット幅が $0.01 \mathrm{~mm}$ で厚さ30mmの タングステン製のものを使用した。エッジは約 2 傾け て撮影して，撮影管電圧は60kVを使用し，スリット はスリット部のディジタル值と，エッジは高露光部の ディジタル值がそれぞれ最大值の $80 \%$ 程度になるよう 

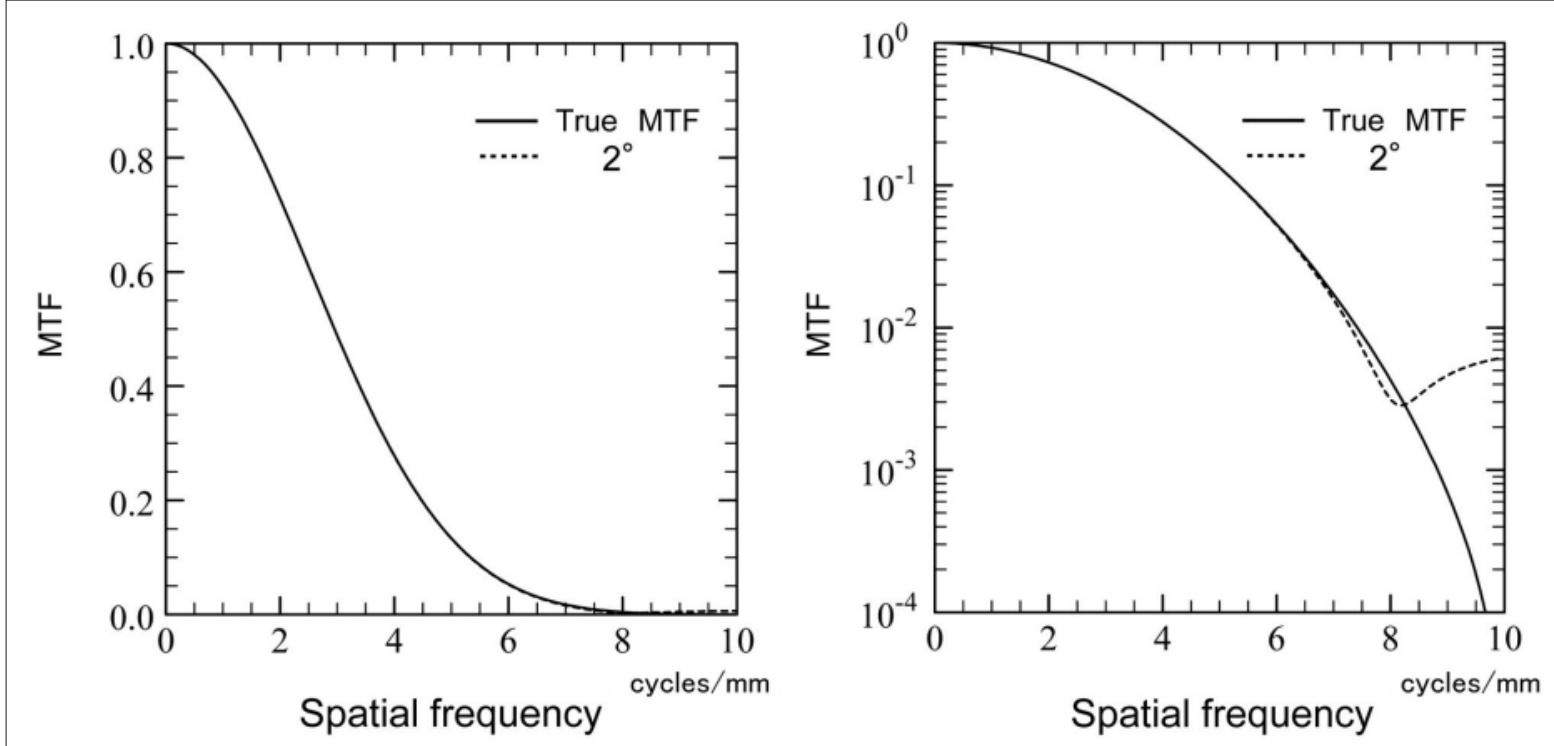

Fig. 4 Presampled MTF calculated from a simulated edge image using the proposed method. A normal vertical linear scale (a) and logarithmic vertical scale (b) are presented.

にmAs值を調節した。得られた画像のローデータをコ ンピュータに転送し，視覚的に不均一が認められない 領域からエッジが中心となる180×180ピクセルのデー 夕を抽出し合成プロファイルを得た。binの幅はCRの サンプリングピッチが0.175mmであるために，その10 〜 20\%の幅となる $0.03 \mathrm{~mm}$ としてデー夕間隔の均等化 を行い，あらかじめ夕イムスケール法にて得られた特 性曲線を用いて線形化を行い，合成ESFを算出した。 そして，これを微分してLSFを得た後，LSFに対し指 数関数近似による外挿を行い，このフーリエ変換によ り得た結果に対して，binの幅と隣接差分の影響に対 するsinc関数による補正を行いpresampled MTFを算出 した。スリット法 ${ }^{13)}$ は，エッジとほぼ同じ角度に傾斜 させ，管電圧を同じにして撮影し，Fujitaらの方法4)に 準じて解析した。

\section{2. 結 果}

\section{2-1 シミュレーション}

\section{2-1-1 基本的な精度の検討}

シミュレーションにて作成したサンプリングピッチ $0.1 \mathrm{~mm}$ で 2 傾けたエッジ像から本手法にて算出した MTFをFig. 4に示す. Fig. 4(a)では解析結果と真值は 一致しているようにみえるが，縦軸を対数表示にした Fig. 4(b)では6.5cycles/mmあたりから真值との誤差を 生じているのが確認できた。真值との誤差が 0.001 以

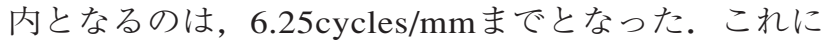
より，本手法がナイキスト周波数5.0cycles $/ \mathrm{mm}$ までは 十分に正確なMTFが求められ，それ以上の周波数では わずかながら誤差を生じることが示された.

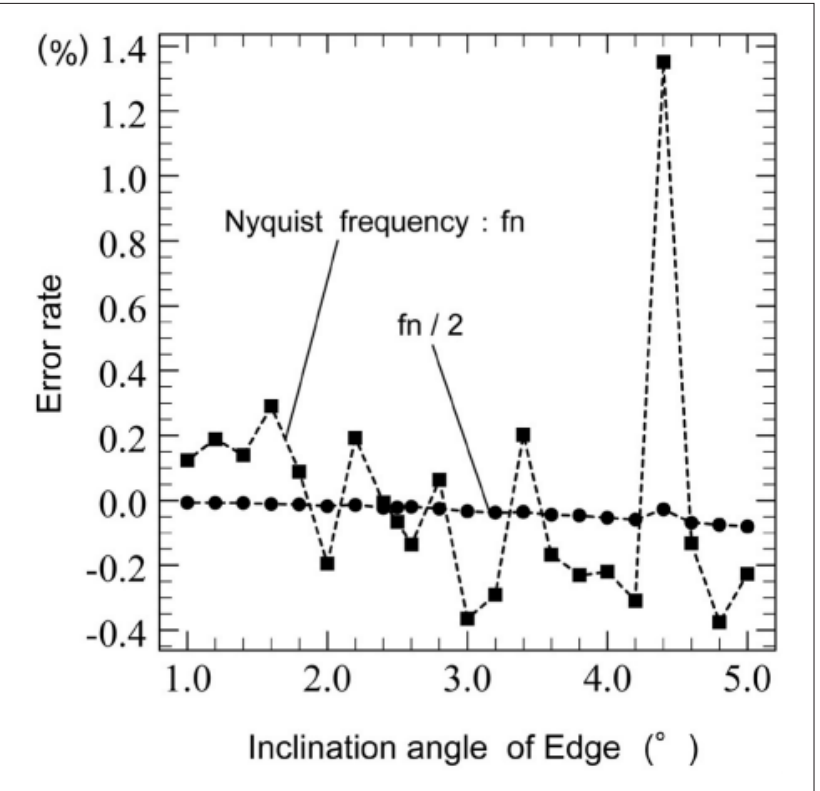

Fig. 5 Relation between the inclination angle of the edge and the error rate of calculated MTF. The changes at $f n / 2$ and $f n$ are presented.

\section{2-1-2 各因子のMTF測定值への影響}

a)エッジの傾斜角度の影響

Fig. 5は，エッジの傾斜角度の変化によるナイキス 卜周波数 $\mathrm{fn}$ とその半分の周波数 $\mathrm{fn} / 2$ における誤差率の 変動を示したものである。傾斜角度 $1 \sim 5^{\circ}$ 内において 周波数 $\mathrm{fn} / 2$ では誤差率は-0.1 0\%の範囲となり，角度 が大きくなるに従ってMTF值はわずかに減少した。ま た，周波数fnでは誤差率は-0.4 1.4\%の範囲となり， 傾斜角度 $4.4^{\circ}$ を除いた場合では誤差率は-0.4〜0.3\%の 

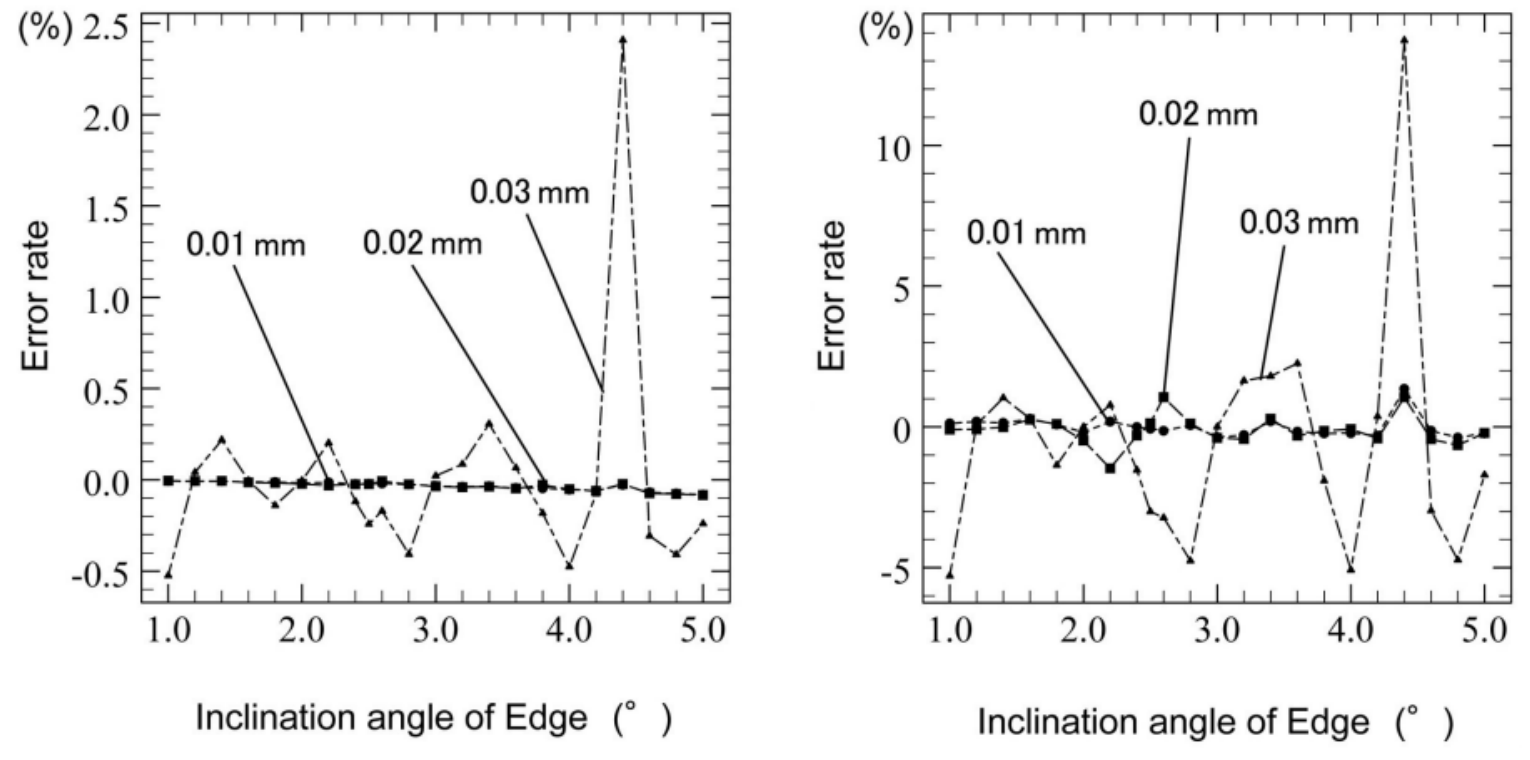

Fig. 6 Relations between angle of edge and error rate of calculated MTF obtained with bin widths of $0.01,0.02$, and $0.03 \mathrm{~mm}$. The changes at $(\mathrm{a}) \mathrm{fn} / 2$ and $(\mathrm{b}) \mathrm{fn}$ are presented.

$a \mid b$

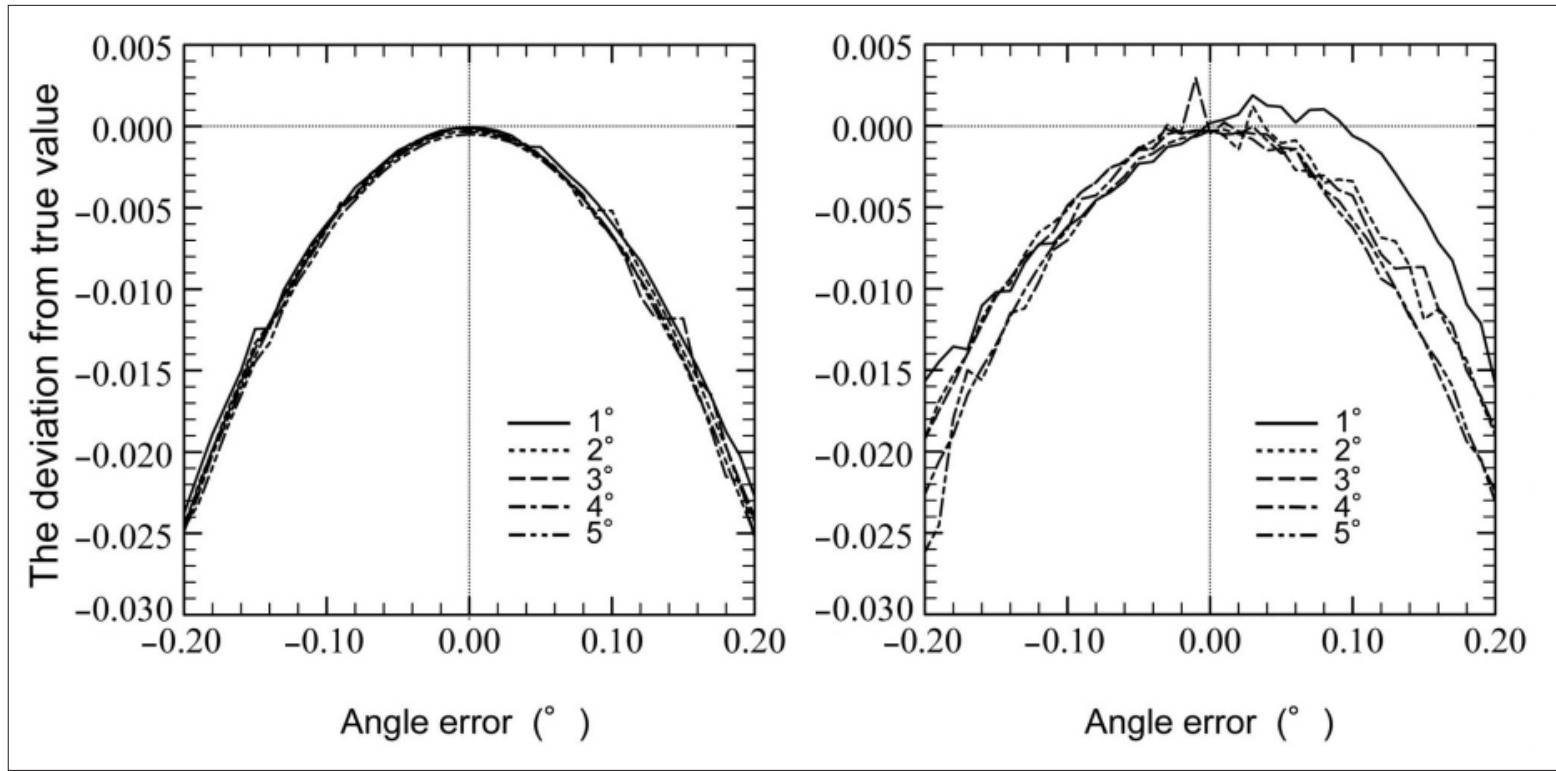

Fig. 7 Relations between edge angle error and deviation from true MTF value with different edge angle. The changes at $(\mathrm{a}) \mathrm{fn} / 2$ and $(b) \mathrm{fn}$ are presented.

$\mathrm{a} \mid \mathrm{b}$

範囲となった。

\section{b) binの幅による影響}

Fig. 6は，エッジの傾斜角度を $1 \sim 5^{\circ}$ の範囲で変化さ せて, 各binの幅に対する解析結果と真值の誤差率の 変動を示したものである。fnとfn/2の双方において， binの幅が $0.01 \mathrm{~mm}$ と $0.02 \mathrm{~mm}$ の場合に誤差率は小さ く，かつ安定した結果を示した。 $0.03 \mathrm{~mm}$ の場合には 傾斜角度によって誤差率が大きく変化して不安定な結 果となった。

\section{c) エッジの角度の計測誤差による影響}

Fig. 7は，真の角度と合成に用いる角度の誤差に対 するMTF值の誤差の変化を示したものである.fnおよ びfn/2 ともに，真值との角度の誤差が大きくなるほど MTF值は低下していき，エッジの傾斜角度が大きいほ ど角度誤差がMTFへ及ぼす影響が大きくなった。誤差 の影響はエッジの傾斜角度により異なったが， $\pm 0.05^{\circ}$ 以下の角度誤差であれば周波数 $\mathrm{fn} / 2$ でMTF值の誤 差は $-0.0025 \sim 0$ 程度となり，周波数 $\mathrm{fn}$ では-0.0025〜 0.003 程度となった。 また， $\pm 0.10^{\circ}$ 以下の角度誤差の 
場合は周波数fn/2でMTF值の誤差は-0.007〜0 程度と なり周波数 $\mathrm{fn}$ では-0.007〜0.003程度となった。

d)ノイズによる影響

ノイズ付加によるMTFの算出過程で得られるLSFを

Fig. 8に示して, MTFの変化をFig. 9に示した. Buhr らの方法ではノイズを抑えるために30のESFを平均し たが，LSFの形状はFig. 8のように大きく振動して外 挿を行うポイントをみつけることが困難であった。こ のため，Buhrらの方法では外挿なしでのMTFのみ算 出した。一方，本手法では0.01 mmのbinの幅によって 平滑化するため，LSFはFig. 8のようにノイズ抑制が されており，外挿を行うに值する曲線となった。Fig. 9(a)はLSFの外挿なしでの本手法とBuhrらの方法の比 較である。両者は真值を中心に振動するような結果を 示した. Fig. 9(b) は本手法におけるLSFの外挿のあり となしの場合の比較である。外挿によって，真值とほ ぼ一致した結果となった。

\section{2-2ＣR装置の実測による本手法とスリット法の比較}

Fig. 10は，CR装置の実測における本手法とスリッ 卜法の比較である。両者の解析結果は，ほぼ一致した ものとなった。

\section{3. 考 察}

エッジ法によるMTF測定はスリット法と比べて画像 取得が容易であるが，ESFの微分操作によるノイズの 増幅が正確な解析を難しくする。このため，Buhrらや Sameiらは，ノイズの軽減を目的にESFの平滑化や曲 線近似を行っているが，有効な対策にまで至っていな

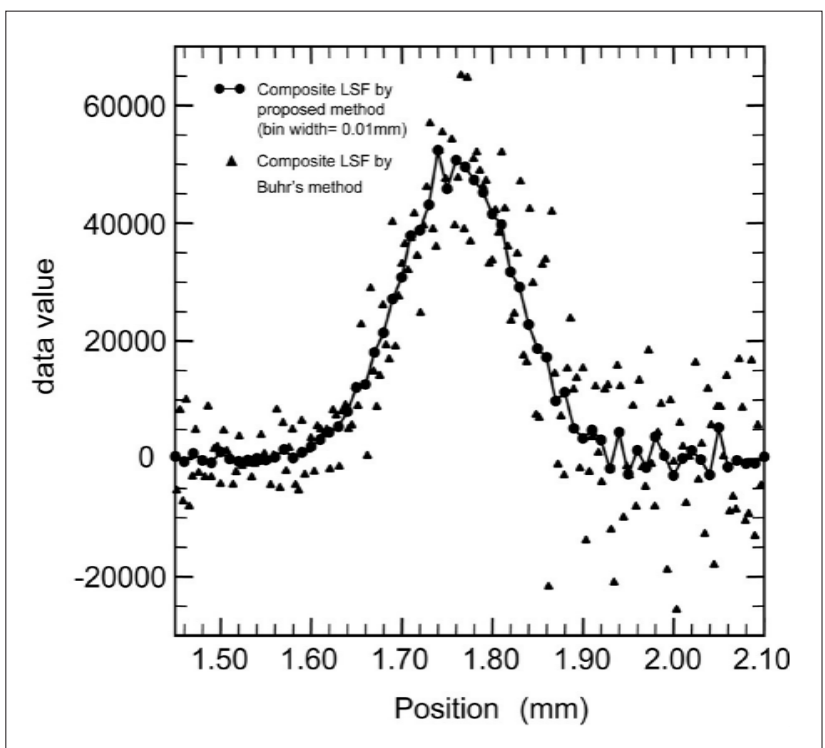

Fig. 8 Composition LSFs calculated from the simulated edge image that added the noise by Buhr's method and the proposed method.

い.これに対して，比較的広い範用のデータを利用し 多数のエッジプロファイルを合成する本手法は，ノイ ズの影響を軽減するために有効な手法であることが確 認できた。

またシミュレーションによる各因子の影響の検討 では，傾斜角度が5 という比較的大きな角度でも真值 との誤差率はナイキスト周波数で-0.4 $1.4 \%$ 以内で $4.4^{\circ}$ を除いた場合では-0.4〜0.3\%以内となり，予想に 反して少ないものであった。ここで傾斜角度が $4.4^{\circ}$ に て誤差率が大きくなるのは，1/tan4.4が12.996とほぼ

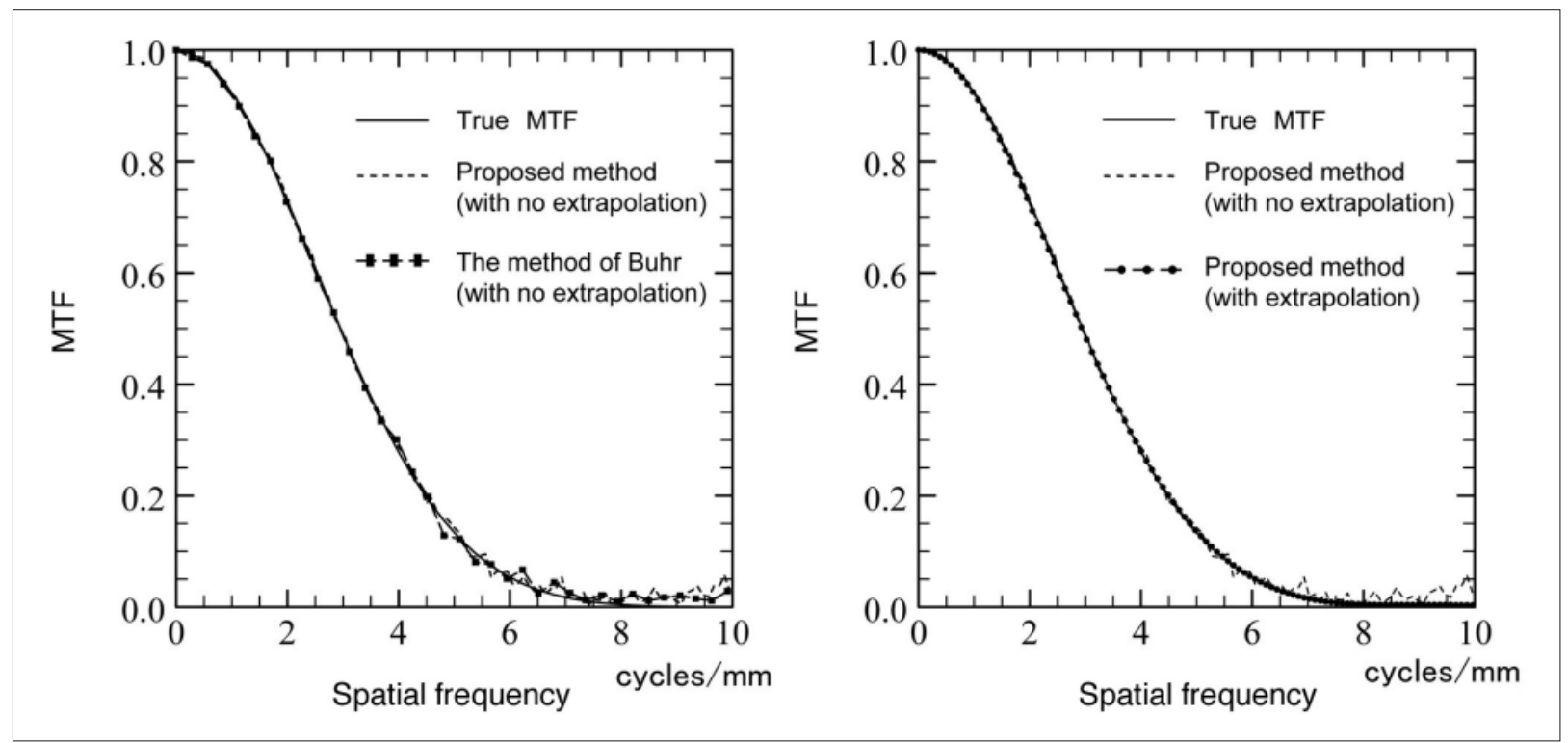

Fig. 9 Presampled MTFs calculated from the simulated edge image that added the noise with normal distribution and true MTF. (a) shows results by Buhr's method and the proposed method with$a \mid b$ out extrapolation. (b) shows results by the proposed method with and without extrapolation. 


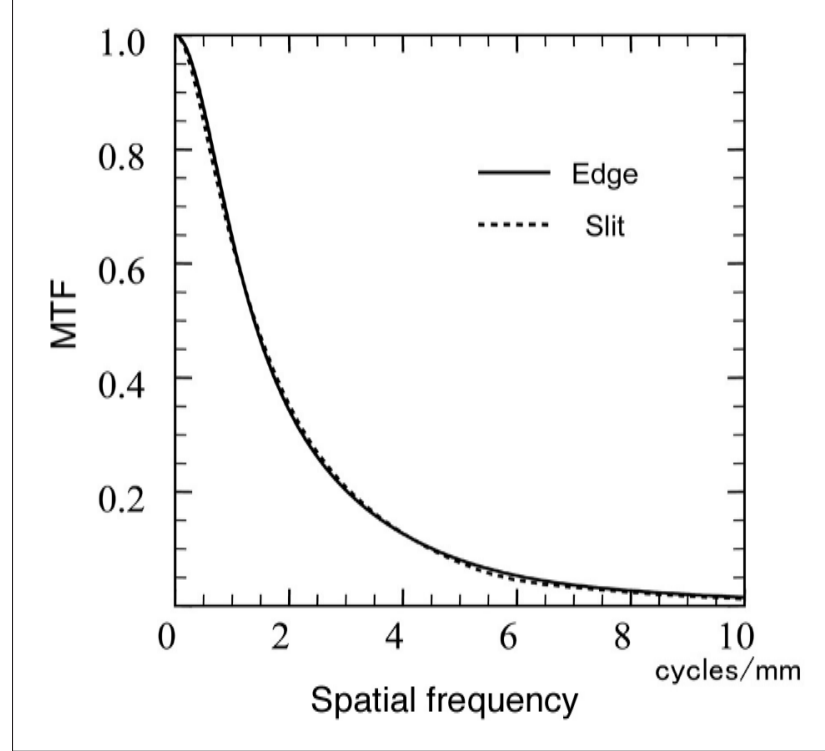

Fig. 10 Presampled MTFs of a CR system measured by the proposed method and the slit method.
整数となっていることが原因と考えられる. 傾斜角度 を $\theta$ として $1 / \tan \theta$ が整数もしくはほぼ整数となる角度 においては，合成したプロファイルのデータ点は(ピ クセルサイズ $\times \tan \theta$ の整数倍の位置に集まる。この場 合，デー夕点が偏った配置になるためにプロファイル データとbinとの位置関係によってbin処理後のプロ ファイルは変化しやすく，MTFの值に影響を及ぼすこ とになる。実際にbinの幅を $9 \cdot 10 \cdot 11 \mu \mathrm{m}$ として傾斜 角度が4. $4^{\circ}$ に扔ける真值との誤差および誤差率を算出

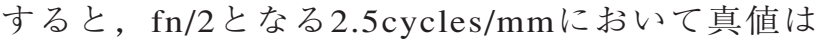
0.609185 で誤差は $0.000064 \cdot-0.000167$ • -0.000459 , 誤差率は $0.010437 \% \cdot-0.027401 \%$ •

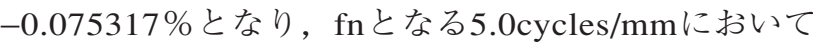
真值は 0.133443 で誤差は-0.000457・0.001803・ -0.000702 ，誤差率は-0.342233\%・1.350852\% • $-0.526132 \%$ となる。 binの幅を $9 \cdot 11 \mu \mathrm{m}$ とて，プロ ファイルデータとbinとの位置関係がわずかながら 異なることで真值との誤差掞よび誤差率は小さくなっ た。このようにbinの幅を変更することで誤差の少な い解析は行えるものの, 本手法において $1 / \tan \theta$ が整数 もしくはほほ整数となる傾斜角度はできる限り避けた 方がよいといえる。次にbinの幅設定は, サンプリン グピッチの10２0\%程度の幅とすることで安定した結 果を示すことが確認された。さらにbinを用いること は，平滑化が非常に効果的であり，精度の確保に対し て有効であった。角度の計測誤差は， $\pm 0.05^{\circ}$ 以内の誤 差であればナイキスト周波数でMTF值は-0.0025 0.003 程度の誤差となる。しかし, 実際に画像から エッジの傾斜角度を計測する際には，傾斜を計測する ための位置が 1 ピクセル違っただけで，これよりも大 きな誤差を生じる，例えば，エッジ長を約 $30 \mathrm{~mm}$ ，画
像のサンプリングピッチを $0.1 \mathrm{~mm}$ としたとき，角度の 計測位置を 1 ピクセル分誤ると, 角度誤差は約 $0.17^{\circ}$ と なり， $\pm 0.05^{\circ}$ 以下という基準を逸脱する。Fig.11は エッジ画像からプロファイルの合成を行いbinによる 処理をする前のプロファイルを各計測誤差について表 示したものである. 真の傾斜角度が 20 の画像に対して 角度の誤差を-0.03〜 $+0.02^{\circ}$ の範囲において図のような 合成プロファイルの変化となった。 入力の傾斜角度が 真の傾斜角度に近いほど，合成プロファイルは振動の ない 1 本の曲線のようになる。よって，このようなプ ロファイルの視覚的な確認処理を加えることで, 角度 の誤差は $\pm 0.02^{\circ}$ 以内に抑えることができ，計測誤差の 検討より得られた結果からわずかな誤差に抑えること が可能である。

ノイズを付加した場合，本手法がBuhrらの方法より もノイズの影響を受けにくく，外挿に值するLSFの取 得も可能であった．外挿によってtruncation errorを防 ぎ，ノイズの影響を軽減できた。また，合成プロファ イルの生成過程は, 一次元プロファイルへの投影処理 とbinによる処理だけであることから，本手法が簡便 である点でも優れていた. Cunninghamら ${ }^{14)}$ は, エッ ジ法が低周波数領域の精度に優れ，スリット法が高周 波数領域の精度に優れていると報告したが，本手法が ノイズの抑制効果により適切な外挿処理が可能である ことから，高周波における振動が抑えられて精度の向 上につながった。これによりエッジ法の久点をある程 度改善し得る本手法の提案の意義は大きい. CR装置 の実測によってエッジを使った本手法とスリット法を 比較した結果において, 測定されたpresampled MTF の結果が広い周波数範囲でほぼ一致したことは、シ ミュレーションによる解析結果を裏付けるものである. 


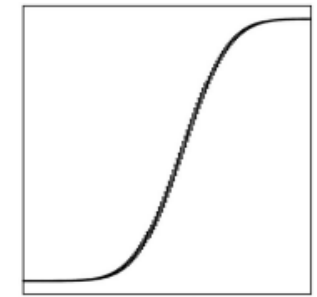

$1.97^{\circ}$

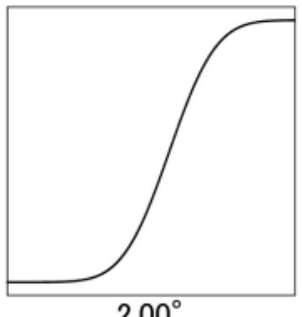

$2.00^{\circ}$

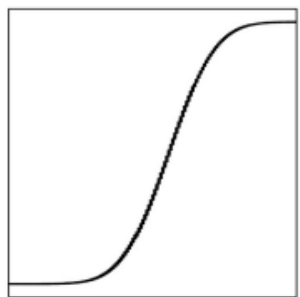

$1.98^{\circ}$

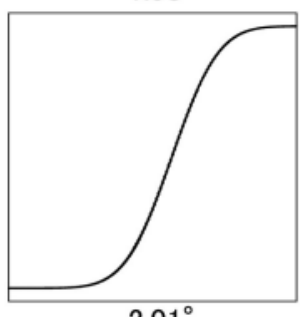

$2.01^{\circ}$

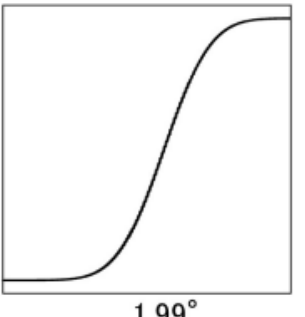

$1.99^{\circ}$

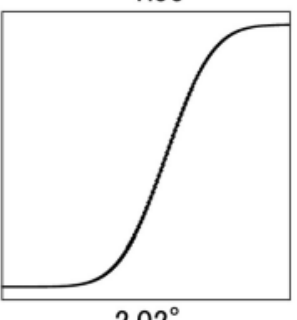

$2.02^{\circ}$

Fig. 11 Composite edge profiles for different edge angle errors.

\section{4. 結 語}

本手法によるエッジ像からのpresampled MTF測定 法は，解析過程における微分操作によるノイズ増幅の 影響を減少させることができ，さらに平滑化されたプ ロファイルにより外挿を可能とした。よって，従来に 提案された手法に比べて，精度が向上した。本手法は 複数のESFを平均するなどの複雑な処理を必要とせ ず，解析手順は非常に簡便であり，ナイキスト周波数 までに制限されず正確なpresampled MTFの算出が可 能な方法である。本手法によってエッジ法の持つ画像
取得の簡便性がさらに強調されることから, detective quantum efficiency (DQE)の測定など装置の性能測定 やquality control (QC) に本法が貢献すると考える.

\section{謝 辞}

本手法の構築において多大な助言をいただきました 日本放射線技術学会中部部会画像研究会諸氏ならびに 日本放射線技術学会画像分科会委員の皆様に御礼申し 上げます。また，ご協力いただきました当院中央放射 線部諸氏に感謝致します。

\section{参考文献}

1) IEC 62220-1. Medical electrical equipment-Characteristics of digital X-ray imaging devices Part 1: Determination of the detective quantum efficiency, ed. 1.0, 2003.

2) Buhr E, Günther-Kohfahl S, Neitzel U. Accuracy of a simple method for deriving the presampled modulation transfer function of a digital radiographic system from an edge image. Med Phys 2003; 30 (9): 2323-2331.

3) Samei E, Ranger NT, Dobbins JT 3rd, et al. Intercomparison of methods for image quality characterization. I. Modulation transfer function. Med Phys 2006; 33 (5): 1454-1465.

4) Fujita H, Doi K, Giger ML. Investigation of basic imaging properties in digital radiography. 6. MTFs of II-TV digital imaging systems. Med Phys 1985; 12 (6): 713-720.

5) Giger ML, Doi K. Investigation of basic imaging properties in digital radiography. I. Modulation transfer function. Med Phys 1984; 11 (3): 287-295.

6）望月安雄，阿部慎司，山口弘次郎．矩形波チャートを用い たコントラスト法でのプリサンプリングMTFの簡易測定. 日放技学誌 $2005 ； 61(9) ： 1355-1357$.

7) 小寺吉衞 編著. 放射線受光系の特性曲線. 医療科学社, 東
京, $1994: 23-83$.

8) 内田 勝, 金森仁志, 稲津 博 著, 日本放射線技術学会 編. 診療放射線技術学大系一専門技術学系 4: 放射線画像 情報工学 I。通商産業研究社，東京，1980：181-187。

9) 桂川茂彦. 4. 画像の評価. 医用画像情報学. 南山堂, 東 京, $2002: 66-91$.

10 ) 畑川政勝, 青木雄二, 朝原正喜, 他. 増感紙一フィルム系 のMTF測定に打けるスリット法と矩形波チャート法の比 較. 日放技学誌 1996 ；52(5)：701-708.

11) 小川智哉 監修, 渋谷道雄, 渡邊八一著. Excelで学ぶフー リ工変換. オーム社, 東京, 2003:71-120.

12) Cunningham IA, Fenster A. A method for modulation transfer function determination from edge profiles with correction for finite-element differentiation. Med Phys 1987; 14(4): 533537.

13) 岡部哲夫編. 医用放射線科学講座 14 医用画像工学. 医歯 薬出版, 東京, 1997：1-81.

14) Cunningham IA, Reid BK. Signal and noise in modulation transfer function determinations using the slit, wire, and edge techniques. Med Phys 1992; 19(4): 1037-1044. 


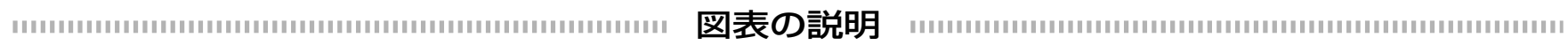

Fig. 1 提案する方法におけるエッジプロファイル合成の概要 $(5 \times 5$ マトリクスの例 $)$

Fig. 2 不規則な間隔の配置である合成プロファイルをbinによって規則的な間隔の配置に変更する概要

Fig. 3 提案する方法によるpresampled MTF測定の解析手順

Fig. 4 提案する方法によってシミュレートされたエッジ像から計算されたpresampled MTF. 縦軸のpresampled MTF值を真数表 示 (a) 㧍よび対数表示 $(\mathrm{b})$

Fig. 5 エッジの傾斜角度一算出されたMTFの誤差率の関係. fn/2およびfnにおける変動を示す.

Fig. 6 エッジの傾斜角度一binの幅を $0.01,0.02$ および $0.03 \mathrm{~mm}$ として得られたMTFの誤差率の関係

(a)fn/2における変動を示す.

(b) fnにおける変動を示す.

Fig. 7 エッジの角度誤差一角度誤差の影響を受けたMTF值と真のMTF值との誤差の関係
(a)fn/2における変動を示す。

(b)fnに扔ける変動を示す.

Fig. 8 シミュレーションによってノイズを付加したエッジ像からBuhrによる方法扮よび提案する方法によって計算された合成LSF

Fig. 9 シミュレーションによってノイズを付加したエッジ像から求めたpresampled MTFと真值

(a)Buhrによる方法(外扫なし) と提案する方法(外挿なし)を示す.

(b) 提案する方法(外挿あり, 外挿なし) を示す.

Fig. 10 提案する方法とスリット法によって測定されたCRシステムのpresampled MTF

Fig. 11 エッジの角度誤差による合成エッジプロファイル 